\title{
A Study Of Authority Control in Spanish University Repositories
}

\author{
Leticia Barrionuevo Almuzara*, $\mathrm{M}^{\mathrm{a}}$ Luisa Alvite Díez ${ }^{* *}$, \\ and Blanca Rodríguez Bravo**** \\ * Library, University of Leon, Campus de Vegazana s/n, \\ 24071 León (Spain), <buffl@unileon.es> \\ $\because$ Library and Information Science, University of Leon, Campus de Vegazana s/n, \\ 24071 León (Spain), <luisa.alvite@unileon.es> \\ $* * *$ Library and Information Science, University of Leon, Campus de Vegazana s/n, \\ 24071 León (Spain), <blanca.rodriguez@unileon.es>
}

Leticia Barrionuevo Almuzara has a degree in Information Science from the University Carlos III of Madrid. She completed a doctorate on 'Knowledge Management and Transfer in the Organizations' and she is now writing her doctoral dissertation on evaluation of institutional repositories. She has been in charge of the Library of the Faculty of Humanities in the University of Leon from 2005, and she is the manager of Buleria, the institutional repository of the Leon University.

$\mathrm{PhD} \mathrm{M}^{\mathrm{a}}$ Luisa Alvite Díez is an assistant professor at the University of León (Spain), Library and Information Science Studies. She has focused her research interests on information retrieval, interfaces, electronic libraries, and digital contents. She has published several works related to these areas in different conference proceedings and scientific journals.

Dr. Blanca Rodríguez Bravo received her Bachelor of History from the University Autonoma of Madrid and her Doctorate of History at the University of Leon. She is a postgraduate in Information Science at the University Complutense of Madrid and in Digital Information at the University Pompeu Fabra of Barcelona. She worked as a librarian at the University of Leon and, since 1991, has been an assistant professor in the Department of Library and Information Science at the University of León teaching subjects related to Knowledge Organization. She participates in a Master Degree of the University of Salamanca about Digital Information Systems. She is author of 3 books and more than 60 papers in journals and conferences, having been head of research projects. Her current research interest focuses on Knowledge Organization in the Digital Age and the Use of Electronic Information in Academic Libraries.

Barrionuevo Almuzara, Leticia, Alvite Díez, Ma Luisa, and Rodríguez Bravo, Blanca. A Study Of Authority Control in Spanish University Repositories. Knowledge Organization. 39(2), 95-103. 12 references.

\footnotetext{
ABSTRACT: This paper examines the current state of authority control development in Spanish university repositories. As a decade has now gone by since the initiation of the first projects for institutional repositories in Spain, it would seem a suitable time to draw attention to authority control, an element of the first rank in evaluating the consistency and integrity of systems for recovering bibliographic information. The work is focused on examining the implementation of authorities in twenty-six Spanish university repositories, taking into account the information provided by the standardization experts working in them. The study considers the responses of the coordinators for these digital collections using a set of analytic criteria set out in the study. The handling of authorities in the group of university repositories studied may be described as uneven. Greater interest may be observed in controlling author entries, with laxer solutions for authority control of subjects. It suggests the need to establish effective poli-
}
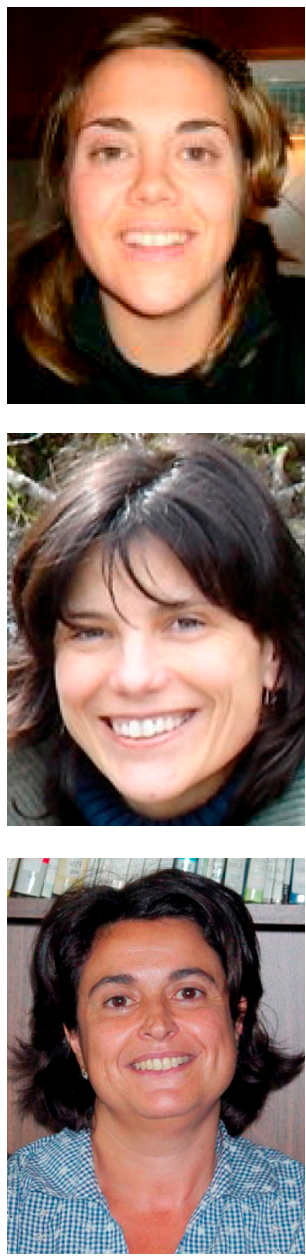
cies for the management of authorities by means of cooperative efforts permitting the building up of corpora of entries for authorities that would aid the processes of cataloguing, metadata creation, and information retrieval in systems based on syntactic and semantic interoperability in which manual intervention should be minimal.

Received 4 November 2011; Accepted 4 November 2011

\subsection{Introduction}

Institutional repositories constitute one of the main tools for the untrammelled diffusion of scientific and cultural information coming from Spanish universities and research centres. They also aspire to serve as an image and identifier for the institutions that they represent. Spain has a good number of university repositories. Several of them are well placed in international rankings (Web ranking of world repositories available at http://repositories.webometrics.info/index_es.html), and the majority are included in academic webcrawlers and search engines, which guarantees a high visibility. Most universities have created their own repositories on an individualized basis with information generated by their teaching staff and researchers. Changes in institutional repositories over recent years has shown an upward trend both in their number and in the quantity of digital objects deposited in them. This growth at an international level has also been reflected in the case of Spain. Thus, from 2001, when TDX (the first repository for doctoral theses) was created, down to the present day, 44 repositories have been set up, the majority of which have been in existence for just two or three years, or even less (Melero et al. 2009).

Nonetheless, the development of these services in Spain may be described as still taking its first faltering steps, if compared with the situation in nearby countries. In general, the volume of objects held is still limited, involvement by university administrations is slight, and there is no great backing by means of institutional mandates or tough policies on open access. The report on the situation of institutional repositories in Spain in 2009, drawn up by the research group Acceso Abierto a la Ciencia [Open Access to Science] summarized the state of development in which these services found themselves:

- There is a great diversity of digital objects lodged in Spanish repositories (books, book chapters, proceedings, working papers, and so forth), but articles and doctoral theses are the types of document most often deposited. Most include metadata and the full text of the documents without any sort of restriction and have a permanent identifier assigned to them.

- The field of natural sciences is under-represented relative to the European average, its place being taken by engineering.

- For the most part, non-proprietary platforms are used. The software most frequently used by institutions to create repositories is DSpace, followed at a considerable distance by EPrints.

- The scheme for metadata most often employed for the description of digital objects held by Spanish institutional repositories is Dublin Core Unqualified.

- With regard to the presence of repositories within other services, they are most often included in the open science harvester Recolecta (http://www.reco lecta.net/buscador) and the international directory OpenDOAR (http://www.opendoar.org/).

- The value-added service most generally implemented in repositories is statistical details on use and access. Nevertheless, administrators consider others to be priorities, such as offices for advising on and promoting open access, citation indexes, personalized services for authors, and the provision of evaluation of research.

- The stimuli for the continuity and maintenance of repositories lie in increased visibility for scientific output, integration of repositories with other information systems, and services that can be set up on the basis of repositories.

- The priorities for the future development of repositories arise from the need for clear policies in respect of access to scientific outputs deriving from finance provided from public funds and the establishment of indicators for quality control in Spanish institutional repositories.

As a decade has now gone by since the initiation of the first projects for institutional repositories in Spain, it would seem a suitable time to draw attention to authority control, an element of the first rank in evaluating the consistency and integrity of systems for recovering bibliographic information. This process involves the standardization of names of people, corporate bodies, and subjects, avoiding con- 
fusions that might be caused by homonyms, synonyms, or variants in names (Herrero Pascual 1999). Authority control acts as a preliminary filter and is a means of achieving precision in retrieval. Unification and differentiation of access points are the basis for all authority control.

The metadata interchange standard OAI-PMH, while offering the possibility of using other formats for metadata, requires all metadata suppliers to provide metadata in Dublin Core format, this being, as pointed out above, the model most often used in Spain. Dublin Core does not incorporate mechanisms for authority control and does not provide the facility of distinguishing controlled entries or of harmonizing variants of a given access point. For these reasons, repositories are still developing consistent approaches for the use of metadata in order to achieve the greatest precision and relevance in retrieval, both from within the repository itself and from harvesters.

There are a number of noteworthy international initiatives aimed at authority control. These run from VIAF (the Virtual International Authority File http://viaf.org/), People Australia (http://www.nla. gov.au/initiatives/peopleaustralia), ISNI International Standard Name Identifier (the draft ISO 27729 http:// www.isni.org), I (Institutional Identifiers of NISO http://www.niso.org/workrooms/i2), and ORCID (Open Researcher and Contributor ID http://www. orcid.org) to specific projects aimed at the control of authors and corporate names in digital repositories, such as the pioneering Names Project (http://names. mimas.ac.uk), financed by JISC in the United Kingdom, and the Co-operative "Identities Hub" of OCLC (http://www.oclc.org/research/activities/idresource). Most of these initiatives are based on cooperation among libraries or institutions that are developing web services for consulting authority files. This joint participation allows lower costs, reduced efforts, avoidance of duplication, and increased usefulness of services. Without a doubt, this collaborative area is the most appropriate place for the development of projects on authority control.

The programs most often used for creating repositories are gradually incorporating more advanced and powerful functionalities related to authority control. Thus, for instance, versions of DSpace earlier than 1.6.0 merely allowed the installation of a module of controlled vocabularies for use in the process of describing documents. This function consisted of a list of terms, hierarchically ordered, that served to categorize by subject the materials lodged in the reposi- tory. These vocabularies did not have to be fixed, since the administrator was able to add personalized lists created for particular purposes. From version 1.6.0 onwards, DSpace has incorporated a specific module for authority control that gives the option of choosing one single entry or value from several that are possible. This aids in inputting the correct metadata, selecting them from a list, and interoperability with other applications outside the program, such as the staff database at the institution and the like.

Moreover, to look at another of the platforms most often used in building up repositories, version 3 of EPrints also incorporates a system for authority control. In this case, the program offers an auto-fill option for authors' names, titles, ISSN, and publisher data for the journals included in the SHERPA/ RoMEO service, besides displaying the policy for selfarchiving that these adopt. In addition, EPrints 3 permits checking for duplications in titles and carrying out global corrections. Although this last feature is not specific to the control of authorities, it is very useful in changing subjects or variants of names in a range of different fields.

\subsection{Objectives and methodology}

The overall aim of this piece of work was to learn of the current state of authority control development in Spanish university repositories. For this purpose, 35 academic repositories, located through the national directory BuscaRepositorios (http://www.accesoabierto. net/repositorios), were selected as the initial object of study. This was intended to allow a first approximation to the solutions adopted for the effective control of access points in these digital archives.

The next step was to establish the criteria to be examined for each of these repositories:

- Control of Access Points for Personal Authors, Corporate Entities and Conferences.

- Control of Geographic Names.

- Control of Chronological Names.

- Terminological Tools Used for Thematic Access: keywords, subject headings, controlled descriptors, classifications, and similar.

- Subject Indexes.

- Subject Languages.

- Authority Standards and/or Controlled Vocabularies.

- Networks of Terms.

- Scope Notes.

- Authority Control Features. 
In order to analyse these points, a questionnaire was sent to the co-ordinators for maintaining the repositories selected. Their responses were used to draw up the detailed table presented in the appendix of this paper. In view of the disparity of the collections being studied, it did not prove feasible to find identical search terms for a systematic exploration and comparison of the solutions adopted and checking of them against the data from the survey. Hence, the work is limited to an examination of the implementation of authorities in 26 Spanish university repositories, taking into account the information provided by the standardization experts working in them. This is a sample which would appear representative in depicting the current state in which academic collections find themselves with regard to authority control.

\subsection{Results}

\subsection{Control of access points for personal authors, corporate entities and conferences}

The long tradition of librarianship in standardizing such authority details would seem to be reflected in the responses provided in respect of implementation of this indicator. Twenty-three of the repositories follow predefined authority models, either for personal name entries, or for the names of corporate or institutional bodies, or for both. If control of access points relating to conferences is considered, only eleven collections include this.

Among the digital archives that maintain a certain standardization of names of authors and corporations, a clear tendency may be observed to formalize authorized entries for the names of members of the particular academic community involved (teaching staff, researchers, candidates for doctorates, students, administrative staff, and so forth), as well as departments, schools, and centres in the institution. In most of these cases, the information is taken from the administration systems that identify personnel in the university. Similarly, a preference can be seen for homogenizing the authority lists of people, entities and conferences in accordance with the access points in the catalogue of the university's library. Hence, in some responses, it was pointed out that the contents included in the institution's catalogue were taken over directly into the digital archive. In some instances, control of personal name authorities was based on the entries that authors used to sign their works. Depending on the academic context in question, researchers may prefer to use the same form of their names in a reposi- tory as that appearing in the various databases in which their publications are included.

\subsection{Control of geographic names and of chronological names}

Although in the repositories considered there was mostly no control over the place names or of periods of time, the prevalent approach in those archives that did include this standardization was very similar to that relating to the first criterion studied. For the most part, control of this sort of entry was undertaken by following the forms employed in the library catalogue. Hence, it was common for chronological periods to be shown as a subject heading within a bibliographic listing (Figure 1).

Furthermore, a similar interest in standardizing the two criteria could be seen among coordinators of repositories, so that, in the table in the appendix, very similar responses appear in column two and column three.

\subsection{Terminological tools used}

Control of subjects in institutional repositories is not an easy task for their coordinators. The scant aid given by computer programs in their earlier versions and the nature of self-archiving involved in a system utilized and manipulated by thousands of users has led standardization of subjects in an open digital archive to be considered, at least up to the present, an impossible task. With regard to the terminological tools used in the repositories studied, the main role was played by lists of subject headings and keywords and, to a lesser degree, classifications, thesauri, and lists of descriptors. Almost all digital archives incorporate an option for the people lodging documents in the repository to be able to put in keywords defining their contents, independently of the subjects that the system itself offers. In this way, the volume of terms without control that may be included in repositories is not limited, a circumstance which would seem to require some form of standardization.

\subsection{Subject indexes}

Indexes for direct access to subjects or keywords were seen as relevant for this study, in view of the undeniable assistance they provide for users when formulating thematic searches. Just three of the digital archives did not offer the option of listing and displaying all subjects in alphabetical order. It is noteworthy that 


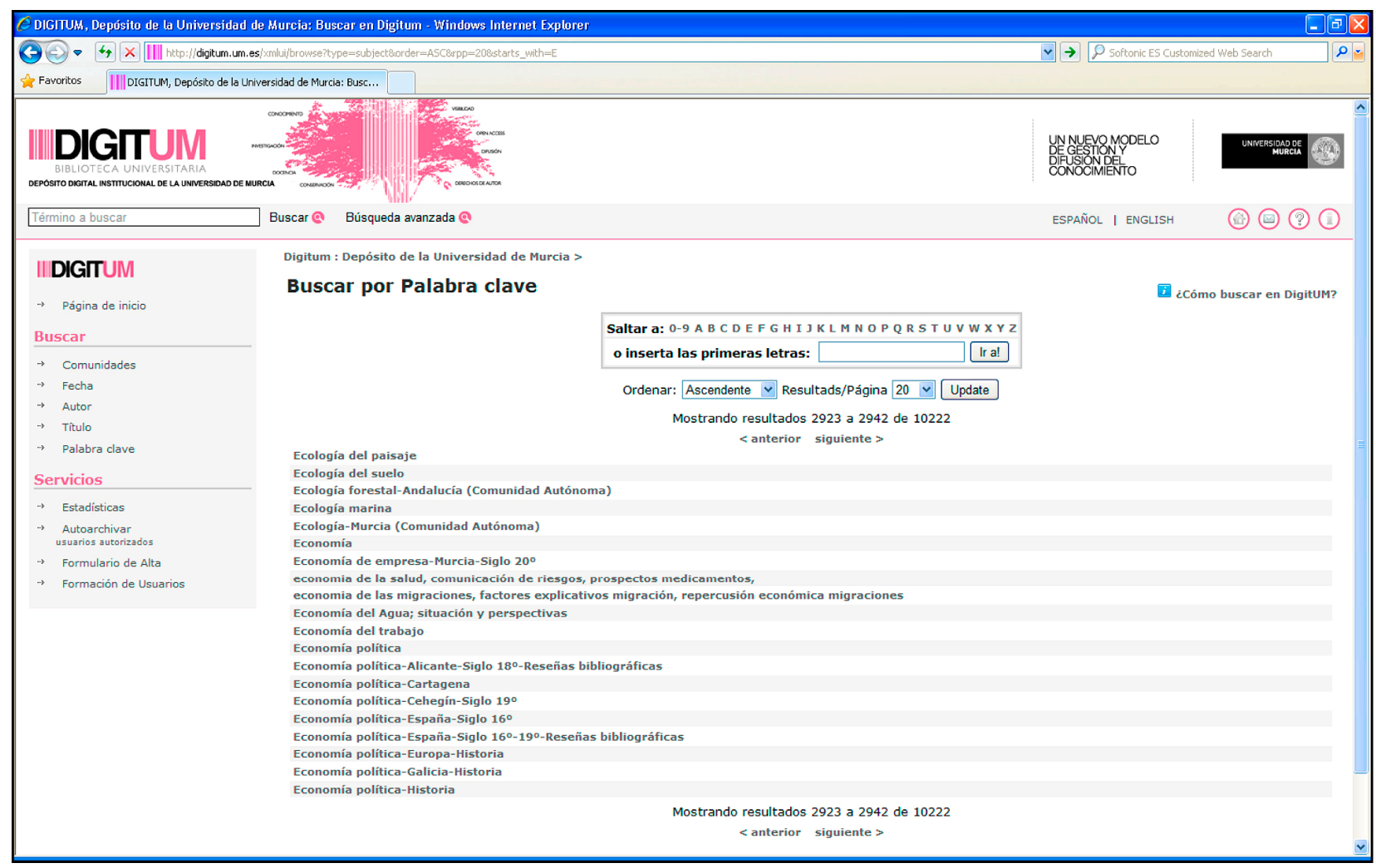

Figure 1. Display of Subjects in Digitum

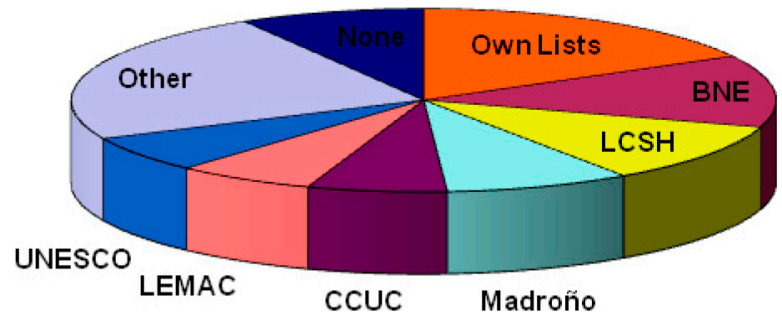

BNE: List of Au-
thorities of the Na-
tional Library of
Spain
CCUC: Authorities
from the Joint Cata-
logue of Universities
of Catalonia

LCSH: Library of Congress Subject Headings

LEMAC: List of Subject Headings in Catalan
Madroño: List of Authorities of the Madroño Consortium

UNESCO: UNESCO Classification

Figure 2. Authority Standards

the repositories not including this function were collections implemented with the platforms DigiTool, Fedora, and CDS Invenio, which are the software packages with the least penetration in Spain.

\subsection{Subject languages}

This indicator is directly related to the visibility of digital collections. Spanish university repositories have mostly implemented subjects in Spanish and English, along with the second official language of the autonomous region where they are sited, when there is such. Seventeen collections decided to facilitate subject access with subject terms in English, versus seven that do so exclusively in Spanish or in Spanish and the language of their autonomous region. Of particular note in this respect are the Rodin repository of the Univer- sity of Cadiz, listing subjects in Spanish, French, English, and Portuguese and the UPCommons repository of the Polytechnic University of Catalonia, a collection in which subjects are quoted in Catalan, Spanish, English, French, Italian, German, and Portuguese.

\subsection{Authority standards and/or controlled vocabularies}

Figure 2 shows the range of systems for authorities and controlled vocabularies found in these collections. It is striking how several models are used in parallel in a number of repositories. In many cases, the choice is a function of the type of document concerned; a clear instance is the use of the UNESCO Classification for the control of dissertations.

In three of the repositories, no reference model is used for authority control, while one of the centres 
surveyed gave no answer for this criterion. The "Others" block covers mentions of the CSIC lists of authorities, list of subject headings of the University of Seville, the subject headings of the Organization of American States, and various thesauri.

It is worth mentioning that classification systems are in use. Thus, the UNESCO model is used in four collections and CDU in the Digibub repository of the University of Granada and the E-Prints set-up of the Complutensian University of Madrid.

In the case of repositories of institution members of the Madroño consortium that use an ad hoc list, it is clear from the responses received that the solutions adopted are far from homogeneous in all the collections using this list of authorities, each university adapting the list to its own particular needs.

It would seem relevant to stress the preference for using individual solutions taken from local library catalogues. On this line, it is significant that studies like Shiri and Chase-Kruszewski (2009) or Walsh (2011) note that the majority choice is to use subject headings from the Library of Congress Subject Headings ( $\mathrm{LCSH}$ ) to organize knowledge in digital collections, despite their undeniable drawbacks. Among these is the difficulty of using them in the case of users who prefer to employ keywords or phrases for the main of their searches. In the case of the Spanish repositories covered here, eight state that they use their own lists and five that they employ the LCSH as a language for control of subjects.

\subsection{Networks of terms}

This indicator can be used to cover the solution adopted by the Open University of Catalonia, which has drawn up a tree chart of thematic areas represented in its teaching and research with the aim of allowing users to select categories or subcategories and filter within them by means of keywords of their choice (Figure 3).

\subsection{Scope notes}

For the moment, none of these 25 collections has implemented notes to any extent in access points to clarify or contextualize the terms employed.

\subsection{Authority control features}

It should be highlighted how, in the responses submitted, those responsible for the repositories expressed their keenness to implement improvements in this area. This might be by specific applications or patches, or through the modules for authorities incorporated in new versions of DSpace or EPrints.

\subsection{Reflections}

The handling of authorities in the group of university repositories studied may be described as uneven. Greater interest may be observed in controlling au-

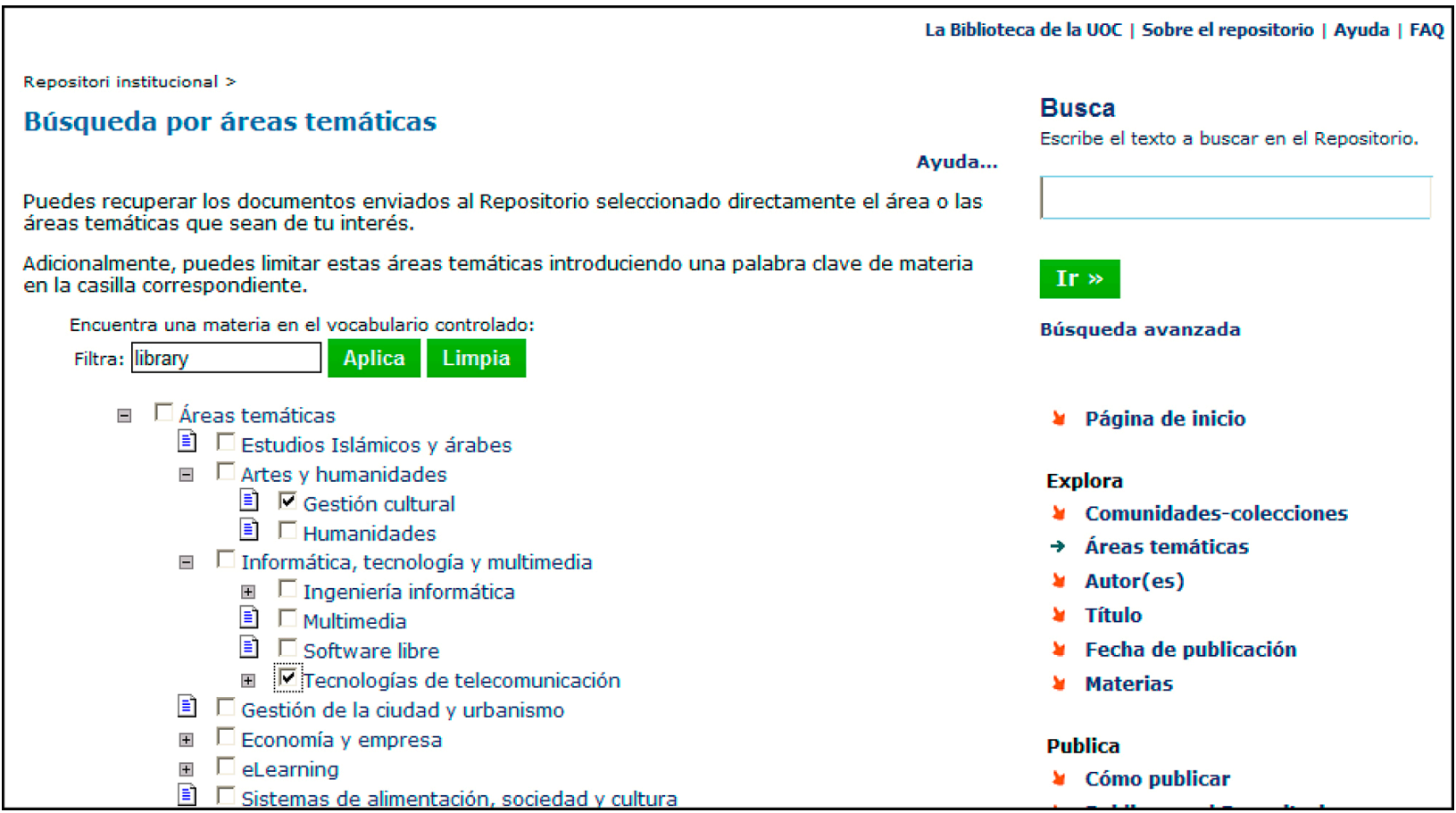

Figure 3. Thematic Areas in $\mathrm{O} 2$ of the Open University of Catalonia 
thor entries, with laxer solutions for authority control of subjects. Most of the repositories have no predefined list of subjects or controlled vocabulary offering those depositing contents a tool to classify documents, or normalizing subjects in an exhaustive way. The use of keywords to categorize the contents of the repository is the preferred choice of the majority of the systems considered. Although these do offer some thematic information on the subjects of materials lodged in the repository, they are not terms that are unambiguous, controlled, standardized, structured, and provided with relational links in the way that the descriptors of a thesaurus are. The results obtained point to a need to establish effective policies for the management of authorities in these types of digital collection through cooperative efforts that will permit the development of corpora of authority entries that will aid the processes of cataloguing, metadata creation, and information retrieval.

The foundations on which the prototype developed by the Names Project of JISC was based, the Functional Requirements for Authority Data (FRAD), interoperability, re-use of data, and minimum manual intervention may point the way for evolution in this field of study. In the subject area, the trend towards interfaces with the capacity to allow multifaceted searching and navigation has led to the development of a prototype in which, on the basis of the representation of LCSH in SKOS, an ontology has been designed to assist users in choosing the correct term by automatically relating the keywords input with the appropriate subject headings in the system (Papadakis et al. 2009). This would appear to be one viable option among those aimed at achieving syntactic and semantic interoperability.

Finally, it should be noted how much effort has been put into the development of software for repository management. Thus, recent versions of the main platforms used (EPrints, DSpace) have incorporated functions to handle authority control. There has even been a study for the implementation of a thesaurus of Greek terms represented in SKOS for DSpace, thanks to work supported by the University of the Minho (Solomou and Papathedorou 2010). All of this is related to the need to open up appropriate data (i.e., linked open data), which logically affects controlled vocabularies, a route in which there is active participation by institutions like the Library of Congress or Europeana, through its Judaica project (http://www. judaica-europeana.eu).

\section{References}

Herrero Pascual, Cristina. 1999. El control de autoridades. Anales de documentación 2: 121-36. Available http://revistas.um.es/analesdoc/article/view/ 2621.

Hill, Amanda, Needham, Daniel, and Danskin, Alan. 2009. Names project, final report. Available http:// www.jisc.ac.uk/media/documents/programmes/ sharedservices/names-phase-one-final-report,.pdf.

Melero, Remedios et al. 2009. Situación de los repositorios institucionales en España: informe 2009. Available http://www.accessabierto.net/sites/default/ files/Informe2009-Repositories_0.pdf.

Montalvo Montalvo, Marilyn. 2011. LCSH, FAST y Delicious: vocabularios normalizados y nuevas formas de catalogación temática. Anales de Documentación 14n1. Available http://revistas.um.es/ analesdoc/article/viewFile/120141/114281.

Orduña-Malea, Enrique, Peset, Fernanda, and FerrerSapena, Antonia. 2009. Análisis de la variabilidad de nombres de autores españoles en depósitos digitales universitarios de acceso abierto: un estudio por áreas de conocimiento. Revista española de documentación científica 32n4: 9-33.

Papadakis, Ioannis, and Michalis Stefanidakis. 2009. Subject-based information retrieval within digital libraries employing LCSHs. D-lib magazine $15 \mathrm{n} 9 /$ 10. Available http://www.dlib.org/dlib/september09/ papadakis/09papadakis.html.

Salo, Dorothea. 2009. Name authority control in institutional repositories. Cataloging $\mathcal{E}$ classification quarterly 47 nos. 3-4: 249-61.

Shiri, Ali and Chase-Kruszewski, Sarah. 2009. Knowledge organisation systems in North American digital library collections. Program: electronic library and information systems 43: 121-39.

Solomou, Georgia D., and Papatheodorou, Theodore. 2010. The use of SKOS vocabularies in digital repositories: the DSpace case. In Proceedings of the 4th IEEE International Conference on Semantic Computing (ICSC 2010), September 22-24, 2010, Carnegie Mellon University, Pittsburgh, PA, USA. Los Alamitos, Calif.: IEEE Computer Society, pp. 542-47. Available http://ieeexplore.ieee.org.ezproxy. lib.uwm.edu/xpls/abs_all.jsp?arnumber $=5628993 \&$ $\operatorname{tag}=1$.

Walsh, John. 2011. The use of Library of Congress Subject Headings in digital collections. Library review 60: 328-43. 
Winer, Dov. 2010. Judaica Europeana: Jerwish semantics in the linked data semantic web - vocabularies. Available http://www.judaica-europeana.eu/docs/ jewish_vocabularies_LOD.pdf.
Xia, Jingfeng. 2006. Personal name identification in the practices of digital repositories. Program: electronic library E information systems 40: 256-67.

\section{Appendix}

\begin{tabular}{|c|c|c|c|c|c|c|c|c|c|}
\hline & $\begin{array}{l}\text { Access } \\
\text { Points }\end{array}$ & $\begin{array}{l}\text { Geo- } \\
\text { graphic } \\
\text { Names }\end{array}$ & $\begin{array}{l}\text { Chronological } \\
\text { Names }\end{array}$ & $\begin{array}{l}\text { Terminolo- } \\
\text { gical Tools }\end{array}$ & $\begin{array}{l}\text { Subject } \\
\text { Indexes }\end{array}$ & $\begin{array}{l}\text { Subject } \\
\text { Languages }\end{array}$ & $\begin{array}{l}\text { Authority } \\
\text { Standards }\end{array}$ & $\begin{array}{l}\text { Networks } \\
\text { of Terms }\end{array}$ & $\begin{array}{l}\text { Scope } \\
\text { Notes }\end{array}$ \\
\hline $\begin{array}{l}\text { Acceda Palmas } \\
\text { Gran Canaria }\end{array}$ & NO & NO & $\mathrm{NO}$ & $\begin{array}{l}\text { Keywords, } \\
\text { Classificati- } \\
\text { ons }\end{array}$ & YES & Spanish & UNESCO & $\mathrm{NO}$ & $\mathrm{NO}$ \\
\hline $\begin{array}{l}\text { AAI Rey Juan } \\
\text { Carlos }\end{array}$ & NO & NO & NO & \begin{tabular}{|l|}
$\begin{array}{l}\text { List of } \\
\text { Subjects }\end{array}$ \\
\end{tabular} & YES & Spanish & MADROÑO & NO & $\mathrm{NO}$ \\
\hline $\begin{array}{l}\text { AD Polytechnic } \\
\text { Madrid }\end{array}$ & $\begin{array}{l}\text { Persons, Enti- } \\
\text { ties }^{1}\end{array}$ & $\mathrm{NO}$ & YES & \begin{tabular}{|l} 
List of \\
Subjects
\end{tabular} & YES & Spanish & MADROÑO & $\mathrm{NO}$ & NO \\
\hline $\begin{array}{l}\text { Arias Montano } \\
\text { Huelva }\end{array}$ & $\begin{array}{l}\text { Persons, Enti- } \\
\text { ties, Confe- } \\
\text { rences }\end{array}$ & YES & YES & $\begin{array}{l}\text { Keywords, } \\
\text { Subject } \\
\text { Headings }\end{array}$ & YES & $\begin{array}{l}\text { Spanish, } \\
\text { English }\end{array}$ & $\begin{array}{l}\text { BNE, Univer- } \\
\text { sity of Seville } \\
\text { Subject Hea- } \\
\text { dings }\end{array}$ & $\mathrm{NO}$ & $\mathrm{NO}$ \\
\hline $\begin{array}{l}\text { Biblos-e Auton. } \\
\text { Madrid }\end{array}$ & $\begin{array}{l}\text { Persons, Enti- } \\
\text { ties }\end{array}$ & NO & $\mathrm{NO}$ & $\begin{array}{l}\text { List of Sub- } \\
\text { jects, Subject } \\
\text { Headings } \\
\end{array}$ & NO & Spanish & $\begin{array}{l}\text { BNE, } \\
\text { MADROÑO }\end{array}$ & $\mathrm{NO}$ & $\mathrm{NO}$ \\
\hline Bulería León & $\begin{array}{l}\text { Persons, Enti- } \\
\text { ties, Confe- } \\
\text { rences }\end{array}$ & YES & YES & \begin{tabular}{|l} 
Keywords, \\
List of \\
Subjects \\
\end{tabular} & YES & Spanish & $\begin{array}{l}\text { BNE, Own } \\
\text { List of Subjects }\end{array}$ & NO & $\mathrm{NO}$ \\
\hline Dadun Navarra & Persons & $\mathrm{NO}$ & $\mathrm{NO}$ & \begin{tabular}{|l} 
Keywords, \\
List of \\
Subjects \\
\end{tabular} & YES & Spanish & $\begin{array}{l}\text { Own List of } \\
\text { Subjects }\end{array}$ & NO & NO \\
\hline $\begin{array}{l}\text { DDD Auton. } \\
\text { Barcelona }\end{array}$ & $\begin{array}{l}\text { Persons, Enti- } \\
\text { ties, Confe- } \\
\text { rences }\end{array}$ & NO & $\mathrm{NO}$ & \begin{tabular}{|l} 
Keywords, \\
Subject \\
Headings \\
\end{tabular} & YES & $\begin{array}{l}\text { Spanish, } \\
\text { Catalan, } \\
\text { English } \\
\end{array}$ & $\mathrm{LCSH}^{2}$ & NO & YES \\
\hline $\begin{array}{l}\text { Digibug } \\
\text { Granada }\end{array}$ & $\begin{array}{l}\text { Persons, Enti- } \\
\text { ties, Confe- } \\
\text { rences }\end{array}$ & YES & YES & $\begin{array}{l}\text { Subject } \\
\text { Headings, } \\
\text { Classificati- } \\
\text { ons } \\
\end{array}$ & YES & $\begin{array}{l}\text { Spanish, } \\
\text { English, } \\
\text { French }\end{array}$ & $\begin{array}{l}\text { BNE, } \mathrm{UCD}^{3} \text {, } \\
\mathrm{OAS}^{4}\end{array}$ & $\mathrm{NO}$ & NO \\
\hline $\begin{array}{l}\text { Digitum } \\
\text { Murcia }\end{array}$ & $\begin{array}{l}\text { Persons, Enti- } \\
\text { ties, Confe- } \\
\text { rences }\end{array}$ & YES & YES & $\begin{array}{l}\text { Keywords, } \\
\text { Subject } \\
\text { Headings, } \\
\text { Descriptors }\end{array}$ & YES & $\begin{array}{l}\text { Spanish, } \\
\text { English }\end{array}$ & $\begin{array}{l}\text { BNE, Own } \\
\text { Catalogue, U- } \\
\text { niversity of Se- } \\
\text { ville Subject } \\
\text { Headings, } \\
\text { Thesauri } \\
\end{array}$ & $\mathrm{NO}$ & NO \\
\hline DD Barcelona & Persons & YES & YES & $\begin{array}{l}\text { Subject } \\
\text { Headings, } \\
\text { Descriptors }\end{array}$ & YES & $\begin{array}{l}\text { Catalan, } \\
\text { English }\end{array}$ & \begin{tabular}{|l|} 
Own Authori- \\
ties Catalogue, \\
Own Thesau- \\
rus \\
\end{tabular} & $\mathrm{NO}$ & $\mathrm{NO}$ \\
\hline Dugi Girona & $\begin{array}{l}\text { Persons, Enti- } \\
\text { ties, Confe- } \\
\text { rences }\end{array}$ & YES & YES & $\begin{array}{l}\text { Subject } \\
\text { Headings, } \\
\text { Keywords }\end{array}$ & YES & $\begin{array}{l}\text { Spanish, } \\
\text { Catalan, } \\
\text { English }\end{array}$ & $\begin{array}{l}\text { AACR2 }^{5}, \\
\text { CANTIC }^{6}, \\
\text { CCUC }^{7}, \text { LE- } \\
\text { MAC }^{8}, \text { LCSH } \\
\end{array}$ & $\mathrm{NO}$ & NO \\
\hline $\begin{array}{l}\text { E-archivo Car- } \\
\text { los III Madrid }\end{array}$ & Persons & NO & $\mathrm{NO}$ & Keywords & YES & \begin{tabular}{|l} 
Spanish, \\
English
\end{tabular} & $\mathrm{NO}$ & NO & NO \\
\hline $\begin{array}{l}\text { e-Espacio } \\
\text { UNED }\end{array}$ & Persons & NO & $\mathrm{NO}$ & Keywords & NO & $\begin{array}{l}\text { Spanish, } \\
\text { English }\end{array}$ & $\mathrm{NO}$ & $\mathrm{NO}$ & $\mathrm{NO}$ \\
\hline
\end{tabular}




\begin{tabular}{|c|c|c|c|c|c|c|c|c|c|}
\hline & $\begin{array}{l}\text { Access } \\
\text { Points }\end{array}$ & $\begin{array}{l}\text { Geo- } \\
\text { graphic } \\
\text { Names }\end{array}$ & $\begin{array}{l}\text { Chronological } \\
\text { Names }\end{array}$ & $\begin{array}{l}\text { Terminolo- } \\
\text { gical Tools }\end{array}$ & $\begin{array}{l}\text { Subject } \\
\text { Indexes }\end{array}$ & \begin{tabular}{|l} 
Subject \\
Languages
\end{tabular} & $\begin{array}{l}\text { Authority } \\
\text { Standards }\end{array}$ & $\begin{array}{l}\text { Networks } \\
\text { of Terms }\end{array}$ & $\begin{array}{l}\text { Scope } \\
\text { Notes }\end{array}$ \\
\hline $\begin{array}{l}\text { E-Prints } \\
\text { Complutensian } \\
\text { Madrid }\end{array}$ & Persons & $\mathrm{NO}$ & $\mathrm{NO}$ & $\begin{array}{l}\text { Keywords, } \\
\text { List of Sub- } \\
\text { jects, Classi- } \\
\text { fications }\end{array}$ & YES & Spanish & $\begin{array}{l}\text { UDC, Own } \\
\text { list of Subjects }\end{array}$ & $\mathrm{NO}$ & $\mathrm{NO}$ \\
\hline EBuah Alcalá & Entities 9 & $\mathrm{NO}$ & NO & $\begin{array}{l}\text { Keywords, } \\
\text { List of } \\
\text { Subjects }\end{array}$ & YES & $\begin{array}{l}\text { Spanish, } \\
\text { English }\end{array}$ & MADROÑO & $\mathrm{NO}$ & $\mathrm{NO}$ \\
\hline $\begin{array}{l}\text { Gredos } \\
\text { Salamanca }\end{array}$ & $\begin{array}{l}\text { Persons, Enti- } \\
\text { ties, Confe- } \\
\text { rences }\end{array}$ & YES & YES & $\begin{array}{l}\text { Keywords, } \\
\text { Subject } \\
\text { Headings, } \\
\text { Descriptors }\end{array}$ & YES & $\begin{array}{l}\text { Spanish, } \\
\text { English }\end{array}$ & $\begin{array}{l}\text { Authorities } \\
\text { Catalogue } \\
\text { USAL, } \\
\text { UNESCO }\end{array}$ & $\mathrm{NO}$ & $\mathrm{NO}$ \\
\hline $\mathrm{O} 2 \mathrm{UOC}$ & $\begin{array}{l}\text { Persons, Enti- } \\
\text { ties, Confe- } \\
\text { rences }\end{array}$ & YES & YES & $\begin{array}{l}\text { Keywords, } \\
\text { Subject } \\
\text { Headings }\end{array}$ & YES & $\begin{array}{l}\text { Spanish, } \\
\text { Catalan, } \\
\text { English }\end{array}$ & $\begin{array}{l}\text { CCUC, IRA- } \\
\text { LIS }^{10}, \text { LCSH- } \\
\text { ES, LEMAC, } \\
\text { VIAF }^{11}\end{array}$ & SI & $\mathrm{NO}$ \\
\hline $\begin{array}{l}\text { RI Jaume I } \\
\text { Castellón }\end{array}$ & Persons & YES & $\mathrm{NO}$ & $\begin{array}{l}\text { Keywords, } \\
\text { Subject } \\
\text { Headings }\end{array}$ & YES & $\begin{array}{l}\text { Catalan, } \\
\text { English }\end{array}$ & $\begin{array}{l}\text { CCUC, } \\
\text { LCSH, LE- } \\
\text { MAC }\end{array}$ & $\mathrm{NO}$ & $\mathrm{NO}$ \\
\hline RTD Burgos & $\begin{array}{l}\text { Persons, Enti- } \\
\text { ties, Confe- } \\
\text { rences }\end{array}$ & $\mathrm{NO}$ & NO & $\begin{array}{l}\text { Keywords, } \\
\text { Subject } \\
\text { Headings }\end{array}$ & YES & $\begin{array}{l}\text { Spanish, } \\
\text { English }\end{array}$ & $\begin{array}{l}\text { BNE, BNF }{ }^{12} \text {, } \\
\text { Own Catalo- } \\
\text { gue, CSIC, } \\
\text { LCSH, } \\
\text { UNESCO }\end{array}$ & $\mathrm{NO}$ & $\mathrm{NO}$ \\
\hline $\begin{array}{l}\text { RiuNet Polyte- } \\
\text { chnic Valencia }\end{array}$ & Persons 13 & $\mathrm{NO}$ & $\mathrm{NO}$ & Keywords & YES & \begin{tabular}{|l} 
Spanish, \\
Valencian
\end{tabular} & & $\mathrm{NO}$ & $\mathrm{NO}$ \\
\hline $\begin{array}{l}\text { Roderic } \\
\text { Valencia }\end{array}$ & Persons ${ }^{14}$ & $\mathrm{NO}$ & $\mathrm{NO}$ & $\begin{array}{l}\text { Classifica- } \\
\text { tions }\end{array}$ & YES & \begin{tabular}{|l} 
Spanish, \\
Valencian, \\
English \\
\end{tabular} & UNESCO & $\mathrm{NO}$ & $\mathrm{NO}$ \\
\hline Rodin Cádiz & Persons & $\mathrm{NO}$ & NO & Keywords & YES & $\begin{array}{l}\text { Spanish, } \\
\text { English, } \\
\text { French, } \\
\text { Portuguese }\end{array}$ & $\begin{array}{l}\text { Own Catalo- } \\
\text { gue }\end{array}$ & $\mathrm{NO}$ & $\mathrm{NO}$ \\
\hline RuA Alicante & $\begin{array}{l}\text { Persons, Enti- } \\
\text { ties, Confe- } \\
\text { rences }\end{array}$ & YES & YES & Keywords & YES & $\begin{array}{l}\text { Spanish, } \\
\text { Catalan, } \\
\text { English }\end{array}$ & $\begin{array}{l}\text { Spanish Cata- } \\
\text { loguing Rules }\end{array}$ & $\mathrm{NO}$ & $\mathrm{NO}$ \\
\hline Ruc Coruña & $\mathrm{NO}$ & $\mathrm{NO}$ & $\mathrm{NO}$ & Keywords & YES & $\begin{array}{l}\text { Spanish, } \\
\text { English }\end{array}$ & $\mathrm{NO}$ & $\mathrm{NO}$ & $\mathrm{NO}$ \\
\hline $\begin{array}{l}\text { UPCommons } \\
\text { Polytechnic } \\
\text { Catalonia }\end{array}$ & $\begin{array}{l}\text { Persons, Enti- } \\
\text { ties, Confe- } \\
\text { rences }\end{array}$ & YES & YES & $\begin{array}{l}\text { Keywords, } \\
\text { Subject } \\
\text { Headings }\end{array}$ & YES & $\begin{array}{l}\text { Spanish, } \\
\text { Catalan, } \\
\text { English, } \\
\text { French, } \\
\text { Italian, } \\
\text { German, } \\
\text { Portuguese }\end{array}$ & $\begin{array}{l}\text { LCSH, } \\
\text { LEMAC, } \\
\text { UPC List of } \\
\text { Descriptors }\end{array}$ & $\mathrm{NO}$ & YES \\
\hline
\end{tabular}

1 Personal Names and Entities (Schools, Departments and Research Centres) in the institution

2 Library of Congress Subject Headings

3 Universal Decimal Classification

4 Subject Headings of the Organization of American States

5 Anglo-American Cataloguing Rules, Second Edition

6 Authorities Catalogue of Names and Titles of Catalonia

7 Joint Catalogue of Universities of Catalonia
8 List of Subject Headings in Catalan

9 Departments in the institution

10 International Registry of Authors-Links to Identify Scientists

11 Virtual International Authority File

12 National Library of France

13 Authors of the institution

14 Authors of the institution 